\title{
Sustainability as a Corporate Strategy: A Performance Comparison of Green and Non-green SME Hotels
}

\author{
Sostenibilidad como Estrategia Corporativa: Una Comparación del \\ Rendimiento entre Pequeños y Medianos Hoteles Ecológicos y \\ Tradicionales
}

Ricardo Teruel-Gutiérrez ${ }^{\mathrm{a}, *} \nabla$ (1)

a) Universidad Politécnica de Cartagena: Cartagena, Murcia (Spain)

* Primary Contact: ricardo.teruel@edu.upct.es (Ricardo Teruel-Gutiérrez)

\begin{abstract}
Sustainability in recent years has gained momentum as a business model, given the challenges facing the economy and society. Small and medium-sized hotel companies have begun to apply new management systems based on sustainability, seeking a dual objective, on the one hand to differentiate themselves from their competition and reach growing market niches, on the other hand to have a more efficient and less polluting business model. When implementing this sustainable management, they also face challenges in its application, such as its lack of regulation by institutions and large investments in innovation. We will carry out an OLS model to identify the internal elements that characterize ecological hotels, and these management systems are being effective for SMEs in Barcelona (Spain)

Keywords: sustainability; eco hotels; SMEs; management

JEL Classification: L10; L83; M14; Q56

Resumen

En los últimos años, la sostenibilidad ha cobrado impulso como modelo de negocio dados los desafíos a los que se enfrenta la economía y la sociedad. Las pequeñas y medianas empresas hoteleras han comenzado a aplicar sistemas de gestión novedosos basados en la sostenibilidad buscando un doble objetivo, por un lado, diferenciarse de su competencia y alcanzar nichos de mercado en crecimiento, por otro, tener un sistema más eficiente y menos contaminante. Al implementar esta gestión sostenible, también enfrentan desafíos en su aplicación como la falta de regulación por parte de las instituciones y las grandes inversiones en innovación. Llevaremos a cabo un modelo MCO para identificar los elementos internos que caracterizan a los hoteles ecológicos y sí estos cambios en la gestión tradicional están siendo efectivos para las PYMEs en Barcelona (España)
\end{abstract}

Palabras clave: sostenibilidad; eco hoteles; PYMEs; gestión

Clasificación JEL: L10; L83; M14; Q56 


\section{Introducción}

The tourism industry is dominated by small and medium-sized companies. 99\% have less than two employees, in addition companies with less than 10 employees represent 95\% (INE, 2019). Given the competition in the sector and the new needs of customers, companies are forced to evolve towards new business models. In recent years, sustainability has become one of the main institutional objectives. Governments have developed different sustainable plans, such as the 2030 agenda for the countries of the European Union or the measures adopted by the member countries of the United Nations. When we examined the "Google Trends" tool, the searches recorded for terms related to sustainability have grown significantly in recent years (Figure 1). The communication of environmental and social responsibility (Herold \& Lee, 2017) and the improvement of organizational performance (Martinez-Martinez, Cegarra-Navarro, Garcia-Perez, \& Wensley, 2019) is considered very important to obtain a competitive advantage and improve the corporate image of SMEs companies, otherwise the measures taken could be considered as cost savings and not as a sustainable measure (Manaktola \& Jauhari, 2007). Suggests that participation in environmental activities may be driven by both economic and ethical considerations (Tzschentke, Kirk, \& Lynch, 2004).

Figure 1. Number of searches with the term "sustainability" in Google

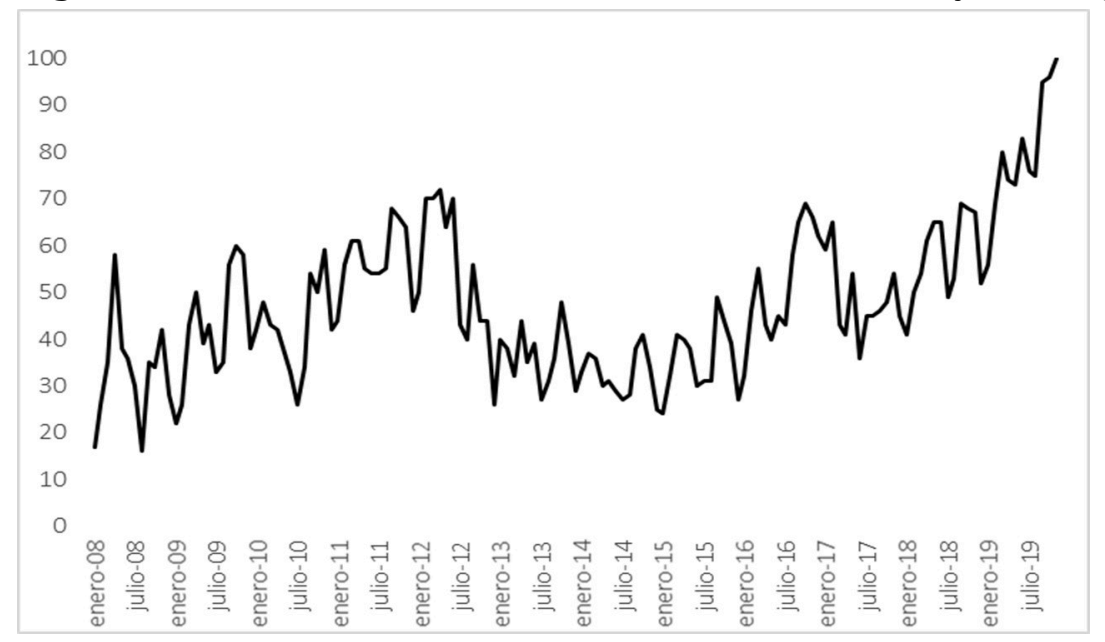

Source: Own elaboration based on Google Trends information

Some researchers have studied the impacts of sustainable development for the small and medium enterprises, giving value to the sustainable management system as a model to obtain competitive advantages in an increasingly demanding market (Côté, Lopez, Marche, Perron, \& Wright, 2008; Fotiadis, Vassiliadis, \& Rekleitis, 2013; Yu \& Bell, 2007), if it is not green washing techniques, it has a significant negative effect on green trust in hotels (Chen, Bernard, \& Rahman, 2019; Trang, Lee, \& Han, 2019). Lee, Hsu, Han and Kim (2010) defines how guests who select an ecological hotel consider that their purchase decision contributes to saving the planet and leaving a green environment for their children, creating a strong competitive advantage over other products that are not sustainable. Although SMEs managers sometimes feel that implementing green practices generates higher prices for the end user and reduces corporate competitiveness (Porter \& van der Linde, 1995; Rosenbaum \& Wong, 2015), these strategies can lead to significant cost reductions through improved resource efficiency such as water and energy, as well as an improvement in waste management (Font, Elgammal, \& Lamond, 2017). Hotels can focus their green practices on four main categories; energy saving, water conservation, recycling, and waste management (Verma \& Chandra, 2018; Han \& Hyun, 2018). According to previous researches (Iwanowski \& Rushmore, 1994; Singh, Cranage, \& Lee, 2014) environmental problems are directly related to your operating costs, and proper management could reduce operating expenses on your property. Reducing waste, energy savings (lighting, heating and air conditioning replacements can be the difference between a SMEs hotel obtaining a higher profitability than its competition and generating great savings, improve the liquidity or invert in sustainable innovations. Furthermore, the more the more advanced sustainable practices in the hotel, the better the impact on consumer satisfaction (Y. Yu, Li, \& Jai, 2017).

Han, Moon and Lee (2019) analyses how this sustainable management is more effective if it is supported by certificates with which the guests can verify the measures taken by the company, this is consistent with the research of Goyal, Rahman and Kazmi (2015), Peiró-Signes, Segarra-Oña, Verma, Mondéjar-Jiménez and Vargas-Vargas (2014) and K.-H. Lee, Lee and Gunarathne (2019). We will use TripAdvisor Green Leaders as a reference. The results of using these certificates intend to pay a higher price. The number of eco-hotels is scarce-approximately a 7\% according with the Eco-Labelling from TripAdvisor ${ }^{1}$.

The objective of this study is to test whether the implementation of an ecological management system is an advantage for hotel SMEs in Barcelona. In this sense, we also tested the existence of spatial concentration 
areas with Ecohotels and specified a Logit model to determine the explanatory factors of the profitability of these hotels based on their operational and internal characteristics. We proposed an empirical model in a sample of SMEs hotels in the city of Barcelona, Spain. With more than 7.2 million international arrivals in 2018, Barcelona is in the Top 20 of the most visited cities in the world, reaching the top 10 on some specific dates (Top Cities Destination Ranking 2017). Thus, to face this situation, traditional hotels seek competitive advantages where the client's preferences are the main objective.

\section{Research background}

Faced with an increasingly demanding market and with a greater number of companies offering similar products, the competitive advantages for SMEs in the tourism sector are very important for their survival and long-term growth (Iraldo, Testa, Lanzini, \& Battaglia, 2017; Özgener \& İraz, 2006), adapting business models to new consumer trends of potential customers.

Competitive advantage can help to position a company in a market in different ways, making it a differentiated service and difficult to imitate in the short term. According to Rangone (1999) we found three ways to competitive advantages for SMEs: innovation, service optimization through management improvements (cost reduction and hotel management improvement) and reputation of brand through market management (where we could include the green image that we represent for clients, such as true certificates and make our sustainable measures known to them). Bohdanowicz (2006), estimates in his study that about $80 \%$ of hotel environmental impacts are due to mismanagement of resources, unnecessarily increasing operating costs. In addition to this competitive advantage, taking green measures by evolving the business model towards sustainable management can have benefits in SMEs in customer satisfaction and the motivation of the organization's own employees (Iraldo et al., 2017; Berezan, Millar, \& Raab, 2014).

However, investment in eco-innovation practices also faces some limitations related to barriers to innovation, such as higher costs in its implementation (Hojnik \& Ruzzier, 2016). García-Pozo, Sánchez-Ollero and Marchante-Lara (2015) and García-Pozo, Sánchez-Ollero and Ons-Cappa (2016) study the impact of ecoinnovation on the labour productivity on a sample of hotels in Spain with positive and significant results. But previous studies do not consider characterising elements of SMEs Eco-Hotels. To fill this gap in the literature we examine to identify the internal elements that characterize ecological hotels, and these management systems are being effective for SMEs in Barcelona (Spain). To do that we focus on the SMEs hotels that obtained the TripAdvisor Green Leaders Certificate -an award based on the ecological practices of the property. We study the characteristics of the hotels to explain the rating and reputation in two different periods.

Therefore, we analyze in this paper whether the hotels that have adopted the option of having management systems based on sustainability have had an improvement in their results at a financial level, compared to conventional hotels. Specifically, as the studies of Ghisetti and Rennings (2014) and Kapiki (2012), we try to check if the innovations in energy efficiency and resources lead to win-win situations, in which reducing the environmental impact of production is contextually improving performance, economic growth of companies and a general improvement in society.

Figure 2. Hotels in Barcelona

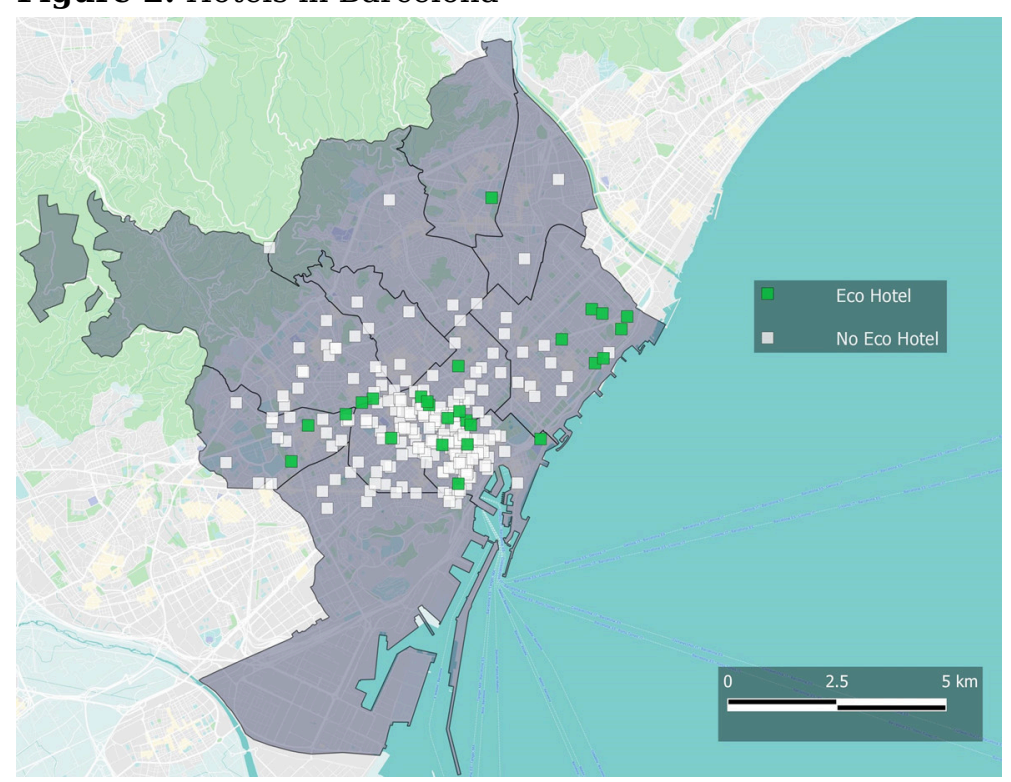

Source: Own elaboration based on TripAdvisor Information 


\section{Methodology and database}

\subsection{Sample and data sources}

To develop this study, we used TripAdvisor dataset which provides information about hotels' characteristics (Diéguez-Soto, Fernández-Gámez, \& Sánchez-Marín, 2017). The hotel selection system considered ECO in TripAdvisor. Based on this information, we chose those hotels branches ${ }^{2}$ in the city Barcelona. For the data collection process, we use web scraping techniques to obtain our sample and the internal and external characteristics of the Eco hotels. Thus, we identify a sample of 335 SMEs hotels with information available. This sample represented a 90\% coverage rate in 2018 (INE, 2019). This information was extracted from TripAdvisor database applying web scrapping techniques to get hotels' variables related to their reputation and general characteristics and their locations. From this sample we get that a $11,5 \%$ of selected hotels have eco-label certifications. To obtain the financial information of each hotel, we will use the SABI database, which we will unify to the previous one for information on the performance of the hotels in different years.

In Figure 2 we can see the location of the different hotels in the city of Barcelona, differentiated by Eco and traditional hotels.

\subsection{Variables}

The rating of the guests towards the hotels is used as a dependent variable as a performance measure. Thus, this is a dichotomy variable which takes the value of one if the hotel has the Eco category and zero in otherwise. The explanatory variables are classified into two categories. (A) Performance indicators of the hotels. Into this category we include the financial variables which evaluates the performance of hotels in the sample for several years. Within this group are the profitability, liquidity, and indebtedness of each hotel. This information will be obtained from the SABI database. According to previous studies, the highly concentrated areas cause more competence and therefore, it is expected a high percentage of Eco-Hotels to face this competitive situation through differentiation.(B) Control variables: Into this category we include general hotels' characteristics such as the size, valuation, price and age. The next Table 1 shows these variables.

Table 1. Descriptive statistics

\begin{tabular}{|c|c|c|c|c|c|}
\hline Variable & Description & ALL & & NO ECO & T-TEST \\
\hline & & \multicolumn{3}{|c|}{$\begin{array}{l}\text { Mean } \\
\text { (std) }\end{array}$} & $\begin{array}{c}\text { Diff } \\
\text { (p-value) }\end{array}$ \\
\hline \multirow[t]{2}{*}{ Eco-Hotel } & \multirow{2}{*}{$\begin{array}{l}1 \text { if hotel is "ECO", } 0 \\
\text { otherwise }\end{array}$} & 0,1061 & 1,0000 & 0,0000 & - \\
\hline & & $(0,3086)$ & $(0,0000)$ & $(0,0000)$ & - \\
\hline \multirow[t]{2}{*}{ Profitability 2012} & \multirow{2}{*}{$\begin{array}{l}\text { Profitability of the hotel in } \\
\text { the year } 2012\end{array}$} & 2,8841 & 2,5990 & 4,5813 & $-0,8919$ \\
\hline & & $(24,5435)$ & $(36,3879)$ & $(20,7015)$ & $(0,3752)$ \\
\hline \multirow[t]{2}{*}{ Profitability 2017} & \multirow{2}{*}{$\begin{array}{l}\text { Profitability of the hotel in } \\
\text { the year } 2017\end{array}$} & 4,3700 & 9,1540 & 8,4860 & 0,2631 \\
\hline & & $(20,4131)$ & $(7,8554)$ & $(22,0415)$ & $(0,7930)$ \\
\hline \multirow[t]{2}{*}{ Size } & \multirow{2}{*}{$\begin{array}{l}\text { log of number of beds in the } \\
\text { hotel }\end{array}$} & 7,8539 & 9,1608 & 7,7580 & 4,7148 \\
\hline & & $(2,4402)$ & $(1,8461)$ & $(2,4899)$ & $(0,0001)$ \\
\hline \multirow[t]{2}{*}{ Average price } & \multirow{2}{*}{$\begin{array}{l}\text { Mean of the price (hotel } \\
\text { room) }\end{array}$} & 81,9900 & 112,5400 & 146,3000 & 2,5883 \\
\hline & & $(0,5154)$ & $(0,4904)$ & $(0,5195)$ & $(0,0121)$ \\
\hline \multirow[t]{2}{*}{ Liquidity 2012} & \multirow{2}{*}{$\begin{array}{l}\text { Liquidity of the hotel in the } \\
\text { year } 2012\end{array}$} & 6,2920 & 10,6701 & 5,2883 & 1,5663 \\
\hline & & $(18,0781)$ & $(29,2182)$ & $(15,8170)$ & $(0,1270)$ \\
\hline \multirow[t]{2}{*}{ Liquidity 2017} & \multirow{2}{*}{$\begin{array}{l}\text { Liquidity of the hotel in the } \\
\text { year } 2017\end{array}$} & 2,8490 & 13,2900 & 2,7640 & 0,5307 \\
\hline & & $(5,1051)$ & $(4,2698)$ & $(5,2611)$ & $(0,5987)$ \\
\hline \multirow[t]{2}{*}{ Debt 2012} & \multirow{2}{*}{$\begin{array}{l}\text { Debt of the hotel in the year } \\
2012\end{array}$} & 57,7300 & 42,9040 & 59,7500 & $-2,8203$ \\
\hline & & $(37,2849)$ & $(30,1982)$ & $(37,7543)$ & $(0,0071)$ \\
\hline \multirow[t]{2}{*}{ Debt 2017} & \multirow{2}{*}{$\begin{array}{l}\text { Debt of the hotel in the year } \\
2017\end{array}$} & 49,7090 & 46,4850 & 50,3280 & $-0,5784$ \\
\hline & & $(29,5329)$ & $(29,8634)$ & $(29,5491)$ & $(0,5669)$ \\
\hline \multirow[t]{2}{*}{ Stars } & \multirow[t]{2}{*}{ Stars of the hotel } & 3,1895 & 3,3269 & 3,2094 & 2,4174 \\
\hline & & $(1,0209)$ & $(1,0273)$ & $(1,0206)$ & $(0,0191)$ \\
\hline \multirow[t]{2}{*}{ Position } & \multirow{2}{*}{$\begin{array}{l}\text { Position of the hotel in the } \\
\text { ranking of TripAdvisor }\end{array}$} & 227,0000 & 151,2000 & 238,3000 & $-3,0047$ \\
\hline & & $(0,9029)$ & $(0,9564)$ & $(0,8931)$ & $(0,0044)$ \\
\hline \multirow[t]{2}{*}{ Rating } & \multirow[t]{2}{*}{ Rating of the hotels } & 7,1040 & 8,5770 & 6,8850 & 2,7676 \\
\hline & & $(1,3916)$ & $(0,6431)$ & $(0,5650)$ & $(0,0085)$ \\
\hline \multirow[t]{2}{*}{ Number of Hotels } & Number of Hotels & 335 & 37 & 298 & - \\
\hline & $\begin{array}{l}\text { \% of subsets of the total } \\
\text { database }\end{array}$ & 100,0 & 11,0 & 89,0 & - \\
\hline
\end{tabular}

Source: Own elaboration

A t-test will be carried out to verify whether the difference between the means of the ECO hotels and the nonECO hotels are significant. 


\subsection{Analyses}

To identify the internal factors that play an important role for the success of business models based on the sustainability of SMEs hotels, and with this the valuation and selection of these above the traditional ones, we will use an OLS model with a multiplicative scheme. (Yip \& Tsang, 2007; Vermeulen \& Barkema, 2001).

The dependent variable rating (number of evaluations * score given by the guests), $X_{i t}(K \times 1)$ represents the independent variables of the model. Assuming a linear distribution, the regression equation would be:

$Y_{i t}=a+b X_{i t}+U_{i t}$

Where $a, b$ are $\beta_{i t}(K \times 1)$ an unknown estimated parameter.

To analyse the effect of the ECO variable (if the hotel performs a management system based on sustainability, it will take the value 1 , in any other case, 0 ) it affects the slope of the explanatory variables, we will create new variables as a product of the variable ECO dummy and explanatory variables, modifying our OLS model as follows:

$Y_{i t}=a+b X_{i t}+c D X_{i t}+U_{i t}$

where $D=1$ if ECO and 0 otherwise and $a, b, c$ are $\beta_{i t}(K \times 1)$ an unknown estimated parameter for any variable. The coefficient $c$ is the differential impact of variable $X$ on customer valuation and a preference $(Y)$ towards ECO hotels.

\section{Results}

\subsection{Exploratory analysis}

It is observed that there is a significant difference between the types of hotels with respect to the logarithm of the number of beds in the hotel, being in average more in the Eco hotels than in the conventional hotels. On the other hand, it is interesting to note how it seemed that Eco hotels have lower profitability on average than conventional hotels in 2012, but over the years, we reached the opposite situation in 2017. In this preliminary study of the variables, we observed a significant difference between the average of valuations, being better in the hotels with Eco attributes. This was verified with t-tests for difference in means in the subsamples. This improvement in the profitability and valuation of eco Hotels in a short period of time, shows an improvement in the reputation of these hotels compared to traditional hotels. In the following section, therefore, the Rating variable will be taken as a dependent variable of the model, hoping to find what factors are positively affecting this business model above the traditional one. A lower financial indebtedness is also observed in Eco hotels. This may be consistent with previous literature since optimal cost management could lead to less indebtedness.

Figure 3. Quartile map of ratings of all hotels

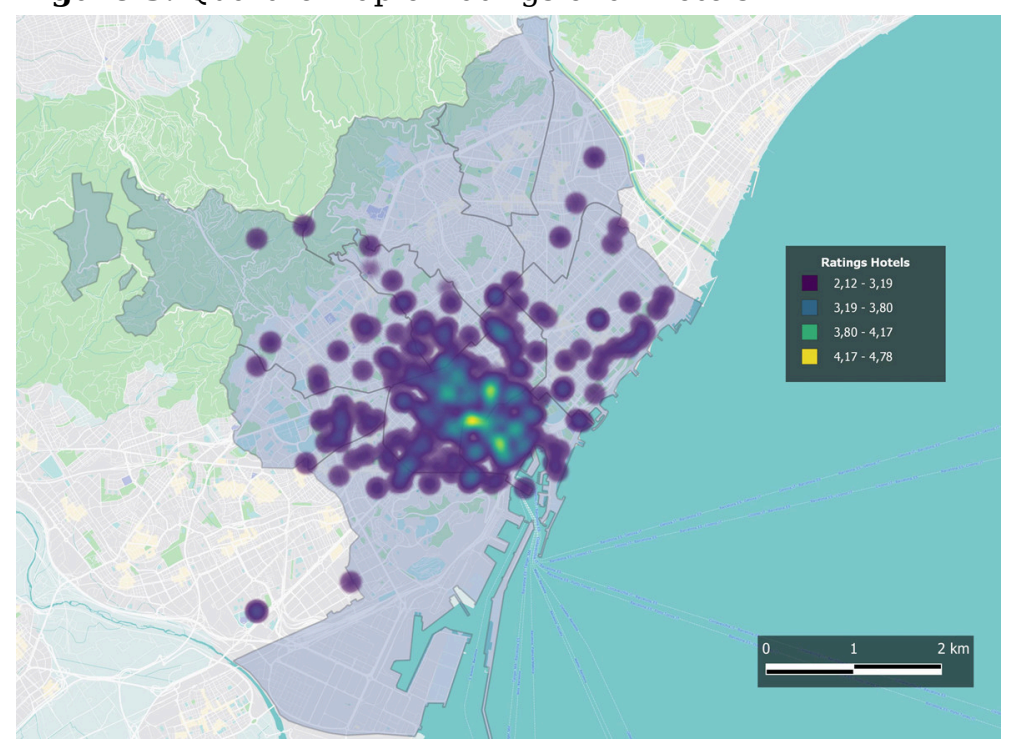

Source: Own elaboration based on TripAdvisor Information 
The rating of the hotels is represented on a quartile map (Figure 3), a certain concentration of the hotels with the highest scores is observed in certain points of the city. In future research, it would be interesting to determine the existence of co-localized spatial patterns in relation to imitation in hotel management.

\subsection{Regression results}

We use an OLS model with a multiplicative scheme to verify that internal, financial and management factors are affecting the valuation of Eco hotels compared to hotels with a traditional management system. With this, we study how the hotels of SMEs that carry out a management system based on sustainability are achieving competitive advantages that cause greater market share and a positive evaluation by customers. Therefore, we will use the Rating variable (total number of comments multiplied by the score). This variable is used as a reputation and valuation reference towards the hotel management model (Lorde, Jacob, \& Weekes, 2019). For the final variables of the model, we applied the general approach to the particular one (Krolzig \& Hendry, 2001), where the non-significant variables were eliminated from the estimation. Table 2 shows the results for the OLS estimate for 2012 and 2017.

Table 2. OLS regression results

\begin{tabular}{|c|c|c|}
\hline \multicolumn{3}{|c|}{ Dependent variable: Rating of costumers } \\
\hline Variables & $\begin{array}{c}\text { OLS } \\
\text { (Year 2012) }\end{array}$ & $\begin{array}{c}\text { OLS } \\
\text { (Year 2017) }\end{array}$ \\
\hline & $\begin{array}{c}\beta \\
(p-v a l u e)\end{array}$ & $\begin{array}{c}\beta \\
(p-v a l u e)\end{array}$ \\
\hline \multirow[t]{2}{*}{ Profitability } & $10,1680^{*}$ & 14,9760 \\
\hline & $(0,1000)$ & $(0,1152)$ \\
\hline \multirow[t]{2}{*}{ Indebtedness } & 7,6770 & 9,9780 \\
\hline & $(0,1426)$ & $(0,2479)$ \\
\hline \multirow[t]{2}{*}{ Size } & $165,8680^{* * *}$ & $168,1692^{* * *}$ \\
\hline & $(0,0000)$ & $(0,0000)$ \\
\hline \multirow[t]{2}{*}{ Average price } & $5,2341 * *$ & $6,0140 *$ \\
\hline & $(0,0286)$ & $(0,0294)$ \\
\hline \multirow[t]{2}{*}{ Position } & $-5,7810 * * *$ & $-5,6420 * * *$ \\
\hline & $(0,0000)$ & $(0,0000)$ \\
\hline \multirow[t]{2}{*}{ Profitability $*$ ECO } & 115.0690* & -30.965 \\
\hline & $(0,0664)$ & $(0,6640)$ \\
\hline \multirow[t]{2}{*}{ Indebtedness $*$ ECO } & $96,3600 * * *$ & $94,602 * * *$ \\
\hline & $(0.0000)$ & $(0.0000)$ \\
\hline \multirow[t]{2}{*}{ Size $*$ ECO } & $69,9800 * * *$ & $71,1838 * *$ \\
\hline & $(0,0003)$ & $(0,0287)$ \\
\hline \multirow[t]{2}{*}{ Average price $*$ ECO } & $-15,9190 * * *$ & $-8,4260 * *$ \\
\hline & $(0,0002)$ & $(0,0053)$ \\
\hline \multirow[t]{2}{*}{ Position * ECO } & $-13,1540 * *$ & $-8,9530 *$ \\
\hline & $(0,0051)$ & $(0,0478)$ \\
\hline Multiple R-squared & 0,5725 & 0,5850 \\
\hline Adjusted R-squared & 0,5513 & 0,5685 \\
\hline
\end{tabular}

$(* * *)$ significant 1\%(**) significant at 5\% (*) significant at 10\%

Source: Own elaboration

The results show that, for both years, a higher position on TripAdvisor represents an improvement in the reputation of the SMEs hotel and a greater probability that customers will book a room above the competition. As the variable product of position * Eco is significant, therefore there is a differential effect on the valuations according to the position in the ranking related to the fact that the hotel has a sustainable management system or not.

Customers value thus the top hotels with ECO management better. This is consistent with Ghisetti and Rennings (2014) and Kapiki (2012). This is an important competitive advantage for the company, and it is important that the company informing customers of the actions that the hotel is taking on a sustainable level (Gürlek \& Tuna, 2018). From our results we also find that there is a positive difference between ecological hotels with respect to traditional hotels, with respect to debt. In the two years, we observed how ecological hotels are more valued than traditional hotels with the same debt levels. This may be due to the measures implemented by hotels with sustainable management. As we have seen in this article, the investment in ecoinnovation, needed to gradually transform the hotel, usually entails great costs for its implementation (Hojnik \& Ruzzier, 2016), but the more advanced these investments in eco-innovation, the greater the impact on consumers (Y. Yu et al., 2017). Given the limitations of our database, it is not possible to confirm that part of this indebtedness belongs to the investment of the improvement of the sustainable management system, but if there is a relationship between the Eco hotels with the greatest increase in benefits in the period and the most indebted in 2012. Another interesting result is found in how the average hotel prices affect the reputation of customers. As the results show, in general a higher average price has a positive effect on the rating of the 
SMEs hotel. Which is different when we do not focus on ECO hotels, since there is a differential effect that causes a higher average price to go against the reputation of the hotel. This effect may be caused by clients' perception of sustainable measures as an attempt to save costs by offering a limited service compared to their competitors (Manaktola \& Jauhari, 2007). It is very important for SMEs to be transparent with customers and explain what are the sustainable measures that the hotel takes, (Han et al., 2019) in addition to having visibility through certificates such as TripAdvisor Leaders.

\section{Concluding remarks}

In recent years, the demand for hotels with sustainable management has increased and customers are increasingly informed about the advantages that this type of business provides at environmental and social levels. SMEs have the opportunity to focus their hotel strategy and management based on these business models, creating competitive advantages over competing hotels. These types of models improve the image of the brand, reduce emissions, and optimize resources and organizational performance (Chang, 2011; Gürlek \& Tuna, 2018). This research studies the behavior of SMEs hotels in the city of Barcelona, looking for differential effects on the factors that affect the reputation and valuation of customers to hotels with sustainable management models and traditional hotels. In our model we found significant differences in some variables.

Our findings indicate, at an exploratory level, that Eco Hotels have a significant improvement at the profitability level in the period 2012 to 2017, going from having a lower average profitability than the hotels with a traditional management to surpass them. This improvement in profitability leads us to propose the model in search of which factors have improved the reputation and number of reservations of SMEs hotels with this management model. On the one hand, the regression points that guests value more than a popular SMEs hotel in the area if it is sustainably managed. Therefore, for customers it is an extra recognition that it has a sustainable management if it is a hotel with a good position on TripAdvisor, obtaining more reservations and with it an increase in profitability. On the other hand, we also found evidence that it is important for hotels to inform customers about their sustainable measures, through certificates or accreditations such as TripAdvisor Leaders or directly to guests. If not, a higher average price can be considered by customers as a savings policy and not as a competitive advantage (Manaktola \& Jauhari, 2007). This effect is considerably reduced in the regression of 2017 with respect to that of 2012 and may be due to the increase in certificates and more information from clients. Lastly, we also found a relationship between the Eco Hotels with the best reputations and the highest indebtedness. The limitations of the database prevent us from knowing exactly if these hotels have a higher indebtedness due to the investment in sustainable innovations, but this would be consistent with the research by Y. Yu et al. (2017).

Finally, this research has limitations that could be considered in future research. This study does not consider the characterization of these ecological hotels based on external environmental factors, nor does it consider the spatially localized contagion effects. Furthermore, the information in our database is limited, given the lack of regulation on the sustainable certificate in the hotel sector and also a growing management model, we have used a certificate that, although reliable, is not a standard. Finally, the study only studies the specific case of Barcelona, the study of alternative locations could corroborate our results.

\section{Acknowledgements}

The author acknowledges the financial support from Fundación Banco Santander.

\section{FootNotes}

${ }^{1}$ https://www.tripadvisor.es

${ }^{2}$ We drop those multinational companies with local headquarters in Barcelona. 


\section{References}

Berezan, O., Millar, M., \& Raab, C. (2014). Sustainable Hotel Practices and Guest Satisfaction Levels. International Journal of Hospitality \& Tourism Administration, 15(1), 1-18. https://doi.org/10.1080/15256480.2014.872884

Bohdanowicz, P. (2006). Environmental awareness and initiatives in the Swedish and Polish hotel industries-survey results. International Journal of Hospitality Management, 25(4), 662-682. https://doi.org/10.1016/j.ijhm.2005.06.006

Chang, C. (2011). The Influence of Corporate Environmental Ethics on Competitive Advantage: The Mediation Role of Green Innovation. Journal of Business Ethics, 104(3), 361-370. https://doi.org/10.1007/s10551-011-0914-x

Chen, H., Bernard, S., \& Rahman, I. (2019). Greenwashing in hotels: A structural model of trust and behavioral intentions. Journal of Cleaner Production, 206, 326-335. https://doi.org/10.1016/j.jclepro.2018.09.168

Côté, R. P., Lopez, J., Marche, S., Perron, G. M., \& Wright, R. (2008). Influences, practices and opportunities for environmental supply chain management in Nova Scotia SMEs. Journal of Cleaner Production, 16(15), 1561-1570. https://doi.org/10.1016/j.jclepro.2008.04.022

Diéguez-Soto, J., Fernández-Gámez, M. A., \& Sánchez-Marín, G. (2017). Family involvement and hotel online reputation. BRQ Business Research Quarterly, 20(3), 151-163. https://doi.org/10.1016/j.brq.2017.05.001

Font, X., Elgammal, I., \& Lamond, I. (2017). Greenhushing: the deliberate under communicating of sustainability practices by tourism businesses. Journal of Sustainable Tourism, 25(7), 1007-1023. https://doi.org/10.1080/09669582.2016.1158829

Fotiadis, A. K., Vassiliadis, C. A., \& Rekleitis, P. D. (2013). Constraints and benefits of sustainable development: a case study based on the perceptions of small-hotel entrepreneurs in Greece. Anatolia, 24(2), 144-161. https://doi.org/10.1080/13032917.2012.741049

García-Pozo, A., Sánchez-Ollero, J. L., \& Marchante-Lara, M. (2015). Eco-innovation and management: an empirical analysis of environmental good practices and labour productivity in the spanish hotel industry. Innovation, 17(1), 58-68. https://doi.org/10.1080/14479338.2015.1011057

García-Pozo, A., Sánchez-Ollero, J., \& Ons-Cappa, M. (2016). ECO-innovation and economic crisis: a comparative analysis of environmental good practices and labour productivity in the Spanish hotel industry. Journal of Cleaner Production, 138, 131-138. https://doi.org/10.1016/j.jclepro.2016.01.011

Ghisetti, C., \& Rennings, K. (2014). Environmental innovations and profitability: how does it pay to be green? An empirical analysis on the German innovation survey. Journal of Cleaner Production, 75, 106-117. https://doi.org/10.1016/j.jclepro.2014.03.097

Goyal, P., Rahman, Z., \& Kazmi, A. A. (2015). Identification and prioritization of corporate sustainability practices using analytical hierarchy process. Journal of Modelling in Management, 10(1), 23-49. https://doi.org/10.1108/JM2-09-2012-0030

Gürlek, M., \& Tuna, M. (2018). Reinforcing competitive advantage through green organizational culture and green innovation. The Service Industries Journal, 38(7-8), 467-491. https://doi.org/10.1080/02642069.2017.1402889

Han, H., \& Hyun, S. S. (2018). What influences water conservation and towel reuse practices of hotel guests?. Tourism Management, 64, 87-97. https://doi.org/10.1016/j.tourman.2017.08.005

Han, H., Moon, H., \& Lee, H. (2019). Excellence in eco-friendly performance of a green hotel product and guests' proenvironmental behavior. Social Behavior and Personality: an international journal, 47(12), 1-10. https://doi.org/10.2224/sbp.8317

Herold, D., \& Lee, K. (2017). The Influence of the Sustainability Logic on Carbon Disclosure in the Global Logistics Industry: The Case of DHL, FDX and UPS. Sustainability, 9(4), 601. https://doi.org/10.3390/su9040601

Hojnik, J., \& Ruzzier, M. (2016). What drives eco-innovation? A review of an emerging literature. Environmental Innovation and Societal Transitions, 19, 31-41. https://doi.org/10.1016/j.eist.2015.09.006

INE (2019). Directorio Central de Empresas. DIRCE. 1 de enero de 2019. Retrieved from https://www.ine.es

Iraldo, F., Testa, F., Lanzini, P., \& Battaglia, M. (2017). Greening competitiveness for hotels and restaurants. Journal of Small Business and Enterprise Development, 24(3), 607-628. https://doi.org/10.1108/JSBED-12-2016-0211

Iwanowski, K., \& Rushmore, C. (1994). Introducing the Eco-Friendly Hotel. Cornell Hotel and Restaurant Administration Quarterly, 35(1), 34-38. https://doi.org/10.1177/001088049403500104

Kapiki, S. (2012). Implementing sustainable practices in greek eco-friendly hotels. Journal of Environmental Protection and Ecology, 13(2), 1117-1123. Retrieved from http://www.jepe-journal.info/vol-13-no-2a

Krolzig, H., \& Hendry, D. F. (2001). Computer automation of general-to-specific model selection procedures. Journal of Economic Dynamics and Control, 25(6-7), 831-866. https://doi.org/10.1016/S0165-1889(00)00058-0 
Lee, J., Hsu, L., Han, H., \& Kim, Y. (2010). Understanding how consumers view green hotels: how a hotel's green image can influence behavioural intentions. Journal of Sustainable Tourism, 18(7), 901-914. https://doi.org/10.1080/09669581003777747

Lee, K., Lee, M., \& Gunarathne, N. (2019). Do green awards and certifications matter? Consumers' perceptions, green behavioral intentions, and economic implications for the hotel industry: A Sri Lankan perspective. Tourism Economics, 25(4), 593-612. https://doi.org/10.1177/1354816618810563

Lorde, T., Jacob, J., \& Weekes, Q. (2019). Price-setting behavior in a tourism sharing economy accommodation market: A hedonic price analysis of AirBnB hosts in the caribbean. Tourism Management Perspectives, 30, 251-261. https://doi.org/10.1016/j.tmp.2019.03.006

Manaktola, K., \& Jauhari, V. (2007). Exploring consumer attitude and behaviour towards green practices in the lodging industry in India. International Journal of Contemporary Hospitality Management, 19(5), 364-377. https://doi.org/10.1108/09596110710757534

Martinez-Martinez, A., Cegarra-Navarro, J., Garcia-Perez, A., \& Wensley, A. (2019). Knowledge agents as drivers of environmental sustainability and business performance in the hospitality sector. Tourism Management, 70, 381-389. https://doi.org/10.1016/j.tourman.2018.08.030

Özgener, Ş., \& İraz, R. (2006). Customer relationship management in small-medium enterprises: The case of Turkish tourism industry. Tourism Management, 27(6), 1356-1363. https://doi.org/10.1016/j.tourman.2005.06.011

Peiró-Signes, A., Segarra-Oña, M., Verma, R., Mondéjar-Jiménez, J., \& Vargas-Vargas, M. (2014). The Impact of Environmental Certification on Hotel Guest Ratings. Cornell Hospitality Quarterly, 55(1), 40-51. https://doi.org/10.1177/1938965513503488

Porter, M. E., \& Linde, C. (1995). Green and competitive: ending the stalemate. Harvard Business Review, 73(5), 120-134. https://doi.org/10.1016/0024-6301(95)99997-E

Rangone, A. (1999). A resource-based approach to strategy analysis in small-medium sized enterprises. Small Business Economics, 12, 233-248. https://doi.org/10.1023/A:1008046917465

Rosenbaum, M. S., \& Wong, I. A. (2015). Green marketing programs as strategic initiatives in hospitality. Journal of Services Marketing, 29(2), 81-92. https://doi.org/10.1108/JSM-07-2013-0167

Singh, N., Cranage, D., \& Lee, S. (2014). Green strategies for hotels: Estimation of recycling benefits. International Journal of Hospitality Management, 43, 13-22. https://doi.org/10.1016/j.ijhm.2014.07.006

Trang, H. L. T., Lee, J., \& Han, H. (2019). How do green attributes elicit pro-environmental behaviors in guests? The case of green hotels in Vietnam. Journal of Travel \& Tourism Marketing, 36(1), 14-28. https://doi.org/10.1080/10548408.2018.1486782

Tzschentke, N., Kirk, D., \& Lynch, P. A. (2004). Reasons for going green in serviced accommodation establishments. International Journal of Contemporary Hospitality Management, 16(2), 116-124. https://doi.org/10.1108/09596110410520007

Verma, V. K., \& Chandra, B. (2018). Sustainability and customers' hotel choice behaviour: a choice-based conjoint analysis approach. Environment, Development and Sustainability, 20(3), 1347-1363. https://doi.org/10.1007/s10668-017-9944-6

Vermeulen, F., \& Barkema, H. (2001). Learning through acquisitions. Academy of Management Journal, 44(3), 457-476. https://doi.org/10.2307/3069364

Yip, P. S. L., \& Tsang, E. W. K. (2007). Interpreting dummy variables and their interaction effects in strategy research. Strategic Organization, 5(1), 13-30. https://doi.org/10.1177/1476127006073512

Yu, J., \& Bell, J. N. B. (2007). Building a sustainable business in China's small and medium-sized enterprises (SMEs)u. Journal of Environmental Assessment Policy and Management, 09(01), 19-43. https://doi.org/10.1142/S1464333207002718

Yu, Y., Li, X., \& Jai, T. (2017). The impact of green experience on customer satisfaction: evidence from TripAdvisor. International Journal of Contemporary Hospitality Management, 29(5), 1340-1361. https://doi.org/10.1108/IJCHM-07-2015-0371 